\title{
BEZPIECZEŃSTWO SPOLECZNE WE WSPÓLCZESNEJ KAMBODŻY: KWESTIA PEDOFILII I SEKSTURYSTYKI JAKO JEDEN Z ASPEKTÓW HANDLU DZIEĆMI
}

Kambodża jest państwem o burzliwej przeszłości politycznej oraz radykalnie zmieniającej się na przestrzeni lat gospodarce. W historii rządzone było przez ugrupowania, które bezpośrednio wpływały na rozwój lub degradację państwa. Określony poziom gospodarczy przyczynił się do powstania problemów warunkujących życie mieszkańców Kambodży. Istotnymi kwestiami są wszelkie problemy natury społecznej i ekonomicznej, z jakimi mieszkańcy tego państwa muszą się na co dzień borykać. Wśród nich mocno rozwinięty jest handel ludźmi, zwłaszcza dziećmi, oraz powiązana z nim seksturystyka i pedofilia. Celem artykułu oprócz teoretycznego przedstawienia kwestii pedofilii i seksturystyki, jest również wskazanie powiązania wspomnianej kwestii z problemem handlu ludźmi. Artykuł ma również na celu pokazanie skali zjawiska oraz w jaki sposób państwo stara się zwalczać daną patologię. Czy samemu podejmuje działania służące rozwiązaniu lub zminimalizowaniu skutków danej kwestii, czy może korzysta z innych instrumentów pomocy?

Handel dziećmi dla celów przestępczych, zwłaszcza seksbiznesu jest klasycznym przykładem łamania praw nieletnich i pozbawiania ich szansy na zdrowe dorastanie. Proceder ten jest ściśle powiązany z wszelkimi aspektami wykorzystywania seksualnego. Państwa Azji Południowo-Wschodniej są obszarami szczególnie narażonymi na rozwój oraz powstawanie nowych zjawisk o podłożu handlu ludźmi, zwłaszcza kobietami i dziećmi. Ma to swoje podstawy w niekorzystnej sytuacji gospodarczej mieszkańców, niezadowalającym poziomie egzystencji, poczuciu niskiej wartości życia człowieka, co stanowi efekt krwawych rządów Czerwonych Khmerów oraz szeroko zakrojonej korupcji.

Handel ludźmi stanowi zjawisko coraz bardziej niepokojące. Wywiera ono bardzo szkodliwy wpływ na życie jednostek oraz rodzi poważne konsekwencje dla ekonomicznych, organizacyjnych i społecznych aspektów życia całego społeczeństwa. Proceder handlu obejmuje seksualne wykorzystywanie, ale również wykorzystywanie do pracy, zahaczające często o niewolnictwo oraz dziecięcą pornografię. Ofiary poddawane są: biciu, przemocy, okrucieństwu psychicznemu, gwałtom, zastraszaniu oraz przymusowi. Samo zjawisko, jak również zwalczanie handlu dziećmi i kobietami wzbudza szczególne zainteresowanie międzynarodowej społeczności. Dla polityki międzynarodowej oraz współpracy problem ten stał się jednym z priorytetowych przedmiotów działania, które polega na wprowadzaniu w życie wszelkich regulacji prawnych na poziomie ogólnoświatowym oraz regionalnym (Vermeulen, 2006: 153). 
Precyzyjna definicja omawianego procederu została zawarta w Protokole o zapobieganiu, zwalczaniu i karaniu za handel ludźmi, w szczególności kobietami i dziećmi (dalej: Protokół z Palermo) i według niej handel ludźmi to: „werbowanie, transport, przekazywanie, przechowywanie lub przyjmowanie osób z zastosowaniem gróźb lub użyciem siły, lub też z wykorzystaniem innej formy przymusu, uprowadzenia, oszustwa, wprowadzenia w błąd, nadużycia władzy lub wykorzystania słabości, wręczenia lub przyjęcia płatności lub korzyści dla uzyskania zgody osoby mającej kontrolę nad inną osobą, w celu wykorzystania. Wykorzystanie obejmuje jako minimum wykorzystanie prostytucji innych osób lub inne formy wykorzystania seksualnego, pracę lub usługi o charakterze przymusowym, niewolnictwo lub praktyki podobne do niewolnictwa, zniewolenie albo usunięcie organów" (Pospiszyl, 2008: 270). Według kambodżańskiej ustawy z 1996 r. (ang. the Law on Suppression of the Kidnapping, Trafficking, and Exploitation of Human Beings) przestępstwo handlu ludźmi zostaje popełnione gdy osoba uprowadza inną osobę w celu ruchu, sprzedaży lub prostytucji poprzez zapewnienie jej wszelkich środków, pieniędzy, biżuterii lub poprzez użycie groźby, wymuszenia czy odurzających narkotyków. Osoba dopuszczająca się takiego przestępstwa może zostać ukarana przez pozbawienie wolności na okres 10-15 lat i kara ta zwiększa się do 15-20 lat, gdy ofiara jest w wieku poniżej 15 roku życia. Takie same sankcje stosowane są wobec wspólników przestępcy. Elementami determinującymi popełnienie przestępstwa są: porwanie, przeniesienie osób z jednego miejsca do drugiego, sprzedaż, zmuszenie do prostytucji, obietnica lub groźba (Paillard, 2006: 11-12).

W omawianym zagadnieniu istotne są dwa aspekty. Perspektywa płci oraz wieku. Ze względu na feminizację ubóstwa, brakiem szans zawodowych i edukacyjnych oraz dyskryminacją ze względu na płeć, ofiarami handlu ludźmi głownie padają kobiety. W kwestii perspektywy kolejnej, znaczenie mają różnice wieku w świetle prawa karnego. Mogą one stanowić okoliczności obciążające, gdy ofiarą jest osoba nieletnia lub okoliczności, jakie muszą zaistnieć, aby rozpatrywać proceder jako przestępstwo. Jednocześnie należy zauważyć, iż dzieci są wyjątkowo podatne na wykorzystanie w celach pornograficznych (Vermeulen, 2006: 155).

W drugiej połowie lat 90., do społeczności międzynarodowej napłynęły niepokojące informacje dotyczące masowego wykorzystywania seksualnego dzieci dla celów komercyjnych, w szczególności w państwach Azji Południowo-Wschodniej. Pomimo spotkań przedstawicieli rządów poszczególnych państw, raportów oraz prac organizacji pozarządowych, trudno dotrzeć do szczegółowych analiz zjawiska oraz skali zagrożenia. Brak danych często wykorzystywany jest dla usprawiedliwienia niepodejmowania działań prewencyjnych przez rządy. Kolejnym problemem w zrozumieniu handlu ludźmi jest traktowanie handlu dorosłymi i dziećmi jako tożsamych sytuacji, co uniemożliwia określenie rzeczywistego obrazu. W badaniach rzadko można spotkać rozróżnienie ofiar na np. dzieci czy kobiety oraz rozróżnienie samego procederu na handel dla seksualnych celów i innych (Morawska, 2006: 303).

Według UNICEF większość dzieci, w liczbie około miliona, zmuszanych do pracy w seks biznesie stanowią dziewczęta. Wiele z nich jest ofiarą globalnej sieci handlu, a ich wiek często nie przekracza 10 lat. Najwyższy wskaźnik handlu dziećmi występuje w Brazylii, ChRL, Tajlandii oraz Stanach Zjednoczonych. Proceder ten nie tylko podlega rozwojowi, ale wciąż angażuje coraz to młodsze osoby (Nesbitt, 2007: 46-50). 
W Kambodży prowincją o najwyższym wskaźniku występowania handlu dziećmi jest Svay Rieng. Jest ona usytuowana na południowym-wschodzie nad rzeką Vai Kou i połączona jest ze stolicą Phnom Penh, Wietnamem oraz sąsiednimi obszarami narodową autostradą. Uczęszczanie dzieci do szkoły ponad podstawowej wynosi jedynie $14,8 \%$ i o połowę mniej dziewcząt korzysta tam z systemu edukacji. Prowincja usytuowana przy granicy z Wietnamem wykazuje niski poziom aktywności turystycznej, jednakże znana jest jako miejsce, gdzie handel dziećmi jest często spotykany, ze względu na ekonomiczną podatność oraz łatwy dostęp dla przestępców seksualnych (Renault, 2006: 14).

Analizując treści pięciu kambodżańskich gazet: „Koh Santepheap”, „Rasmei Kampuchea”, „Kampuchea Thmey”, „The Cambodia Daily” i „The Phnom Penh Post”, w pierwszej połowie 2010 roku doszło do siedmiu zgłoszonych przypadków handlu ludźmi, podczas których w sumie przemycono 15 kobiet. Można zaobserwować znaczący wzrost występowania tego typu przestępstw, zestawiając dane z rokiem poprzednim, gdzie odnotowano jedynie 3 przypadki procederu. Siedem z przemycanych dziewcząt pochodziło z Kambodży lub Wietnamu i transportowane było z ostatniego państwa. Zauważyć również należy, iż ofiary w każdym przypadku były nieletnie. Wszystkie dziewczęta były ofiarami kambodżańskiego handlu, a miejscem ich przeznaczenia była stolica Królestwa, Phnom Penh oraz Akndal lub Siem Reap. W przypadki przestępstwa zaangażowanych było osiemnastu handlarzy, w tym dziesięciu mężczyzn i osiem kobiet, pochodzili oni również z Kambodży i Wietnamu. Spośród podejrzanych udało się aresztować siedemnaście osób, jedna z podejrzanych zdołała uciec (ECPAT, 2010).

W świadomości społecznej handel dziećmi funkcjonuje jako zjawisko, które ma na celu sprzedaż młodych dziewcząt do domów publicznych, dla potrzeb prostytucji. Nic bardziej błędnego. Handel dziećmi nie jest ograniczony wyłącznie do zaangażowania w seks biznes ofiary, jest to zjawisko złożone, ewoluujące oraz przybierające bardzo wyrafinowane formy. Najczęściej dzieci-ofiary handlu ludźmi są przeznaczane do żebractwa, nielegalnych adopcji, pracy niewolniczej, usług seksualnych, przemytu narkotyków, produkcji pornografii dziecięcej oraz popełniania innych przestępstw (Morawska, 2006: 304).

Wśród wymienionych przykładów wykorzystywania dzieci, w państwach Azji Południowo-Wschodniej, w Kambodży do czynienia mamy najczęściej z trzema z nich. Angażowanie ofiar przez grupy przestępcze do żebractwa, przemytu narkotyków oraz popełniania innych drobnych przestępstw. Dzieci nie wzbudzają takich podejrzeń co dorośli oraz nie są narażone na odpowiedzialność karną. A ich łatwowierność oraz poddanie opiekunom sprawia, iż stanowią idealnie nadającą się do popełniania przestępstw jednostkę. Niewolnicza praca dzieci, ma oparcie w najtańszej sile roboczej, jaką są nieletni oraz braku doświadczenia i możliwości oceny życiowej sytuacji, w której jest im dane funkcjonować. Sprowadza się to do wykonywania przez dzieci wszelkich czynności jako pewną powinność wobec osób sprawujących nad nimi władzę. Ostatnim przeznaczeniem jest wykorzystywanie seksualne dzieci, zmuszanie ich do pracy jako prostytutki oraz zaangażowanie w produkcję filmów pornograficznych. Dzieci traktowane są jako bezpieczni oraz tani dostarczyciele seksualnych usług. Bezpieczeństwo w rozumieniu zagrożenia zarażenia wirusem HIV sprawia, iż coraz młodsze osoby są 
pożądane dla jednego z najbardziej dochodowych biznesów prowadzonych przez zorganizowane grupy przestępcze (ibidem: 304-305).

Handel ludźmi obok braku edukacji oraz przemocy domowej jest głównym czynnikiem utrudniającym młodym kobietom realizację ich pełnego potencjału w tworzeniu rozwoju gospodarczo-społecznego. W im młodszym wieku ofiary proceder przemytu i sprzedaży dla potrzeb seksbiznesu i nie tylko zaistniał, tym większe są tego konsekwencje psychiczne oraz trudności w prowadzeniu i kształtowaniu własnej drogi życiowej (Achieving, 2010: 42).

Szkodliwość tego typu doświadczeń jest trudna do opisania. Ofiary najczęściej zmuszone są borykać się z tzw. syndromem stresu pourazowego, poczuciem wyuczonej bezradności, objawami lękowymi, zaburzeniami dysocjacyjnymi czy psychozami, jak również z syndromem sztokholmskim, który polega na odczuwaniu sympatii i solidarności ze swoimi oprawcami. Konsekwencje procederu są o wiele cięższe, gdy ofiara doświadczy utraty zdrowia, najczęściej w formie chorób wenerycznych. Najczęściej wiąże się to z brakiem dostępu do odpowiedniej opieki zdrowotnej, który stanowi kolejny problem, z jakim boryka się Królestwo Kambodży (Pospiszyl, 2008: 275-276).

Również istnienie nieskutecznej działalności organów bezpieczeństwa publicznego lub też brak jakiegokolwiek zainteresowania ofiarami i ich problemami utrudnia walkę nie tylko z procederem, ale również poradzenie sobie z konsekwencjami uczestnictwa w procederze przestępczym. Na uwagę zasługuje fakt, iż istnieją sytuacje, w których dochodzi do świadomego działania organów ścigania przeciwko ofiarom w wyniku działań korupcyjnych, przekupstwa czy przestępstw. Wciąnnięcie takiej osoby w nielegalny proceder łamania prawa wraz z brakiem przychylności organów sprawiedliwości może stwarzać ryzyko odpowiedzialności karnej za popełnione czyny, w sytuacji gdy ofiara współuczestniczy w przestępstwie (ibidem: 276).

Młode dziewczęta, które zmuszane są do prostytuowania się, często stają się przestępcami w świetle prawa. Takie sytuacje nie są pojedynczymi przypadkami. Osoby takie oskarżane są o nierząd i aresztowane za nielegalną działalność. Policja państwowa powinna przeprowadzać dochodzenia, jak podejrzana osoba dostała się do seksbiznesu, czy świadczy usługi dobrowolnie, czy została do tego zmuszona oraz czy jest niepełnoletnia i tym samym nie podlega odpowiedzialności karnej. Wśród próby 1800 respondentów przebadanych w Phnom Penh, prowincji Kampong Cham i Oddar Meanchey $83 \%$ osób uważa, iż oskarżanie takiej osoby jest złe, $8 \%$ uważa, że owszem tak powinno być, a $9 \%$ osób jest niezdecydowanych. Pomimo większości głosów na „nie”, zdarzają się opinię naznaczające ofiarę. Wypowiedzi te w większości oscylują wokół zdania, iż dana osoba jednak świadczy usługi seksualne, policja jedynie stara się jej pomóc przez reedukację oraz ofiara była nieposłusznym dzieckiem i nie słuchała rodziców (Children's, 2009: 35-36).

Proceder handlu dziećmi jest przykładem łamania ich praw, wraz z naznaczaniem ofiar sprzyja nie tylko powstawaniu patologii społecznych, ale również powstrzymuje młodego człowieka od własnego rozwoju i prawidłowego wdrażania się w życie społeczne. Prawa człowieka stanowią jeden z głównych obszarów zainteresowania Organizacji Narodów Zjednoczonych, jak również kwestia handlu dziećmi, która stanowi przejaw ich łamania. $Z$ tego względu w latach 90 . przyjęto wiele dokumentów dotyczących przeciwdziałania tym przestępstwom. Do najważniejszych z nich zaliczyć 
można: Konwencję NZ przeciwko międzynarodowej przestępczości zorganizowanej, Protokół o zapobieganiu, zwalczaniu oraz karaniu za handel ludźmi, w szczególności kobietami i dziećmi, Konwencje o prawach dziecka oraz Protokól fakultatywny do Konwencji o prawach dziecka w sprawie handlu dziećmi, dziecięcej prostytucji i dziecięcej pornografii (Koss, 2007: 69-70).

Konwencja przeciwko międzynarodowej przestępczości zorganizowanej wprowadza i definiuje termin zawarty w jej nazwie, jak również precyzuje charakter międzynarodowego przestępstwa. W dokumencie zorganizowana grupa przestępcza oznacza „posiadającą strukturę grupę składającą się z trzech lub więcej osób, istniejącą przez pewien czas oraz działającą w porozumieniu w celu popełnienia jednego lub więcej poważnych przestępstw określonych na podstawie niniejszej Konwencji, dla uzyskania, w sposób bezpośredni lub pośredni, korzyści finansowej lub innej korzyści materialnej" (Konwencja, 2000). Działanie takiej grupy nabiera charakteru międzynarodowego w dwóch sytuacjach. Pierwsza z nich ma miejsce wtedy, gdy przestępstwo zostało popełnione w jednym Państwie, jednakże część przygotowań do niego, kontroli nad nim, planowania i kierowania odbyła się w innym państwie. Druga natomiast wtedy, gdy została popełniona w więcej niż jednym Państwie. Do konwencji dołączono protokoły dodatkowe, z których jeden, Protokót z Palermo, jest kluczowy dla omawianego tematu, ponieważ wprowadza definicję handlu dziećmi, która wykorzystywana jest jako wzór dla innych organizacji. Z kolei Konwencja o prawach dziecka, przyjęta w 1989 r., stanowi zbiór podstawowych praw, jakie należą się każdej niepełnoletniej osobie. Według stanu na styczeń 2014 r. umowa ta obowiązuje aż w 193 państwach, poddając penalizacji czyny w niej określone, do których należą: przemyt dzieci, praca przymusowa i wyzysk, nielegalne adopcje, handel dziećmi oraz seksualne wykorzystywanie. Do wspomnianego dokumentu dołączono protokół fakultatywny, który uszczegóławia przepisy dotyczące handlu dziećmi przez wprowadzenie bardziej precyzyjnej definicji handlu dziećmi w porównaniu do tej zawartej w Protokole z Palermo, szerszej ochrony ich praw, dzięki czemu łatwiejsze staje się jej stosowanie (Koss, 2007: 69-70).

W ramach walki z procederem handlu dziećmi, oprócz stosowania przepisów prawa międzynarodowego oraz monitoringu poszczególnych państw przez ONZ, dużą rolę odgrywają organizacje pozarządowe, prowadzące swoją działalność w zakresie walki oraz pomocy ofiarom przemytu osób i wykorzystywania ich w celach pracy niewolniczej i seksbiznesu.

Rząd państwa boryka się z wieloma trudnościami w rozwiązaniu tej sytuacji, co doprowadziło do powstania lokalnych i zagranicznych organizacji, które często przejmują wykonywanie zadań, które pierwotnie stanowiły obowiązek Ministerstwa Sprawiedliwości oraz urzędników i lokalnych organów ścigania. Przykładem takiej organizacji może być francuska Action Pour Les Enfants, której działalność polega na monitorowaniu potencjalnych przestępców seksualnych zagrażających nieletnim na ulicach największych miast Kambodży. Takie działanie wraz ze zbieraniem informacji, dowodów czy fotografowaniem przestępcy wraz z ofiarami, jak również uzyskiwanie zeznań leży w gestii policji. Z powodu słabego systemu sądowego, pomoc organizacji pozarządowych jest nieoceniona. Polega ona przede wszystkim na udzielaniu pomocy prawnej oraz wsparcia prawnego kobietom i dzieciom, przeprowadzaniu szkoleń dotyczących prawa karnego i procedur dla funkcjonariuszy policji oraz urzędników 
sądowych. Skupione są również na angażowaniu ofiar w pracę społeczną oraz reintegrację (Paillard, 2006: 37).

W takiej zależności pomiędzy sektorem administracji publicznej a organizacjami pozarządowymi bardzo ważna jest wzajemna współpraca w celu osiągnięcia oczekiwanych rezultatów walki z handlem dziećmi.

Hendel dziećmi ma wiele obszarów oddziaływania. Jednym z nich jest mocno rozwinięta w Kambodży kwestia pedofilii i seksturystyki, która stanowi jeden z aspektów handlu żywym towarem i wymaga podejmowania doraźnych oraz długofalowych kroków dla zminimalizowania negatywnych skutków procederu oraz w przyszłości całkowitej eliminacji problemu.

Wśród przyczyn powstania patologii społecznej, jaką jest pedofilia i związanej z nią seksturystyki można doszukiwać się wielu czynników generujących rozwój danego zjawiska. Do najistotniejszych z nich należą konsekwencje wynikające z prowadzenia antyglobalistycznych i krwawych rządów Komunistycznej Partii Kambodży, zwanej potocznie Czerwonymi Khmerami, ubóstwa społeczeństwa oraz zakorzenionej w mentalności mieszkańców Kambodży korupcji urzędników państwowych i zwykłych obywateli.

Problem pedofilii i powiązanej z nią seksturystyki, wyrósł na podłożu przemian ekonomiczno-społecznych. Gwałtowność i ogrom wprowadzanych zmian w strukturze społecznej oraz zmienność uwarunkowań gospodarczych negatywnie wpłynęła na sytuację życiową ludności khmerskiej. Od lat borykając się z wszechogarniającą bieda, głodem, zachwianym systemem wartości oraz korupcją, mieszkańcy Kambodży próbują dostosować się do nowej rzeczywistości w jakiej przyszło im żyć. Należy jednak pamiętać, iż taka aklimatyzacja jest trudna do osiagnięcia i wymaga wielu lat usilnego przyzwyczajania się jednostki do dużych i szybko wprowadzonych zmian życiowych.

Występujące w Kambodży problemy społeczne są łagodzone na wiele sposobów, gdyż ich rozwiązanie jest zbyt optymistyczną perspektywą, o nikłych szansach na realizację. Wśród wielu patologii omawianych przez światową prasę, za najistotniejsze uznać można brak szkolnictwa podstawowego zwłaszcza edukacji seksualnej i edukacji dziewcząt oraz szeroko rozumianą demoralizację społeczeństwa (Detyna, 2005: 120).

Ta ostatnia zawiera $\mathrm{w}$ sobie wiele zjawisk związanych $\mathrm{z}$ przemocą i nielegalną działalnością. Demoralizacja obejmuje między innymi takie patologie jak: korupcja, przemoc domowa, praca dzieci, prostytucja, narkomania, pedofilia czy wszelkiego rodzaju grabieże i zabójstwa. Wśród niektórych problemów społecznych, z jakimi boryka się współczesna Kambodża, najprężniej rozwijającą się patologią stała się pedofilia i powiązana z nią seksturystyka (ibidem).

Wykorzystywanie seksualne dzieci, w kulturach świata, mentalności ludzi oraz w oczach społeczności międzynarodowej stanowi jedno z najgorszych naruszeń praw człowieka. Postrzegane jest za najbardziej haniebny czyn krzywdzenia drugiej osoby. Powiązane jest to $\mathrm{z}$ bezwarunkową niewinnością i prawem do ochrony przed zagrożeniami, jakiej dzieci oczekują od osób dorosłych. Kwestia pedofilii i stosowanie przemocy psychicznej i fizycznej względem nieletniego doszczętnie burzy poczucie bezpieczeństwa i komfortu życia ofiary, którą najczęściej są osoby o nie wykształconym do końca systemie wartości, będące w trakcie budowania własnej świadomości.

W grupie przestępstw seksualnych, pedofilia zajmuje coraz wyższą pozycję pod względem ilości przypadków. Należy ona do przestępstw o charakterze ujawniania 
skłonności do zaspokajania pragnień erotycznych z udziałem nieletnich. Funkcjonuje wiele definicji opisujących dane praktyki. Rozpatrując kwestię teoretyczną zjawiska, należy pamiętać, iż nie każdy lubieżny czyn z udziałem dziecka musi świadczyć o pedofilii, jednakże gdy te kontakty seksualne stanowią nadrzędną i dominującą formę zaspokajania seksualnych potrzeb jednostki, wtedy dane działania należy nazwać pedofilią (Podgajna-Kuśmierek, 2003: 34-35).

Generalnie mianem pedofilii określić można wszelkie podejmowane działania seksualne wobec dzieci, które najczęściej nie osiagnęły dojrzałości fizycznej. Jednakże jak wielu jest badaczy zajmujących się tym zagadnieniem, tak wiele definicji można przytoczyć. Różnorodność tłumaczenia kwestii związana jest z różnymi kontekstami oraz aspektami poruszanymi podczas badań nad zjawiskiem. Część osób naukowo rozpatrujących omawianą patologię społeczną skupia się na jej przyczynach i determinantach powstania, inni skupiają się na skutkach psychicznych i fizycznych ofiar, które doświadczyły przemocy, jeszcze inni starają się teoretycznie przedstawić zakres działań podlegających pod omawianą dewiację seksualną.

Pedofilię, dosyć precyzyjnie, zdefiniować można jako: „zboczenie polegające na uzyskiwaniu satysfakcji seksualnej z molestowania - pieszczenia, masturbowania, czasem pełnego stosunku seksualnego - z dziećmi, które nie weszły jeszcze w okres pokwitania" (Klimasiński, 2000: 53). Definicja ta zobrazowuje zespół działań i praktyk wykonywanych $\mathrm{z}$ udziałem nieletnich $\mathrm{w}$ celu zaspokojenia potrzeb seksualnych oprawcy. Innym określeniem dewiacji, skupiającym w swoim opisie profil ofiary jest definicja Ewy Jarosz z Uniwersytetu Śląskiego. W myśl definicji: „dzieckiem seksualnie wykorzystywanym uznać można każdą jednostkę w wieku bezwzględnej ochrony, jeżeli osoba dojrzała seksualnie, czy to przez świadome działanie, czy też przez zaniedbanie swoich społecznych obowiązków lub obowiązków wynikających ze specyficznej odpowiedzialności za dziecko, dopuszcza do zaangażowania dziecka w jakąkolwiek aktywność natury seksualnej, której intencją jest seksualne zaspokojenie osoby dorosłej" (Jarosz, 1998: 22).

Najczęstszymi czynnikami wpływającymi na rozwój skłonności pedofilnych są frustracja seksualna, niedojrzałość powiązane z brakiem pewności siebie, fobiami seksualnymi czy alkoholizmem. Część z nich tworzona jest na bazie własnych doświadczeń z okresu dzieciństwa, w których najczęściej oprawca stanowił ofiarę przestępstwa. Związek z tym mają zaburzenia komunikacji interpersonalnej, częste konflikty, silny egocentryzm czy autorytaryzm oraz specyficzny charakter pełnienia ról w rodzinie. Takie wydarzenia generują dewiacyjne zachowania i wpływają na późniejsze przedmiotowe traktowanie dziecka, czy pozbawianie go tożsamości społecznej (Podgajna-Kuśmierek, 2003: 34-35).

Państwem, w którym proceder wykorzystywania seksualnego nieletnich jest bardzo rozwinięty, ignorowany i rzadko obarczany konsekwencjami prawnymi, jest Królestwo Kambodży. To właśnie tam zjeżdżają pedofile, zwłaszcza z krajów zachodu, w celu zaspokojenia potrzeb seksualnych.

W ostatnich latach Kambodża stała się priorytetowym miejscem przeznaczenia dla przestępców seksualnych odwiedzających państwa Azji Południowo-Wschodniej. Jest to pierwszorzędny rezultat przemysłu, jaki stanowi świadczenie usług seksualnych przez kobiety i dzieci. Kolejnymi przyczynami takiego stanu rzeczy są nieadekwatne 
ustawodawstwo, niski wiek ofiar i tym samym mała świadomość prowadząca do szybkiej zgody na lubieżne praktyki oraz sąsiedztwo z krajami, które zapewniają procesy i karalność przestępców seksualnych. Również egzekwowanie prawa na podstawie ubogiej bazy danych i badań oraz niewyedukowanie personelu stanowi barierę przed skuteczną ochroną ofiar pedofilii. Należy jednakże pamiętać, iż najważniejszym czynnikiem generującym zjawisko jest bieda (Action Pour Les Enfants, 2006).

To właśnie bieda stanowi impuls dla wspomnianych praktyk. Popychając ludzi do nielegalnej działalności w celu uzyskania niezbędnych środków do życia, tworzy podłoże dla bezkarnego funkcjonowania seks biznesu. Charakteryzując się wieloma aspektami umożliwia przestępcom seksualnym zapewnienie względnego dobrobytu mieszkańcom biednego państwa, co stanowi kuszącą perspektywę dla ludzi od lat borykających się z trudną sytuacją życiową.

Statystyki pokazują, iż ponad $88,4 \%$ dzieci w największych miastach Kambodży, Phnom Penh i Sihanoukwille, odbyło swój pierwszy stosunek z zagranicznym mężczyzną (Keane, 2006). Bez względu na wiek czy płeć, khmerskie dzieci narażone są na wykorzystanie seksualne oraz konsekwencje psychiczne i fizyczne, z którymi w tak biednym kraju o tak niskim poziomie edukacji trudno walczyć, a co dopiero przezwyciężać.

Najczęstszymi sytuacjami, w których dzieci narażone są na działalność pedofilów jest życie na ulicy, bezdomność czy sieroctwo oraz proceder zwany z języka angielskiego god-fathering, oznaczający sprawowanie opieki nad dzieckiem jako samozwańczy ojciec chrzestny. Występującym w Kambodży zjawiskiem, którego praktykowania rząd stara się ograniczyć, a nawet zakazać, są małżeństwa mieszane, polegające na związku obcokrajowca z zazwyczaj bardzo młodą obywatelką Kambodży.

Wyspecjalizowana agencja Organizacji Narodów Zjednoczonych - UNICEF definiuje „dzieci” ulicy jako osobę poniżej osiemnastego roku życia, która żyje lub spędza większość czasu na ulicach zurbanizowanych obszarów, zajmując się sobą lub własną rodzina, poprzez podejmowanie prac dorywczych lub żebrząc. UNICEF również wyróżnia dwa typy dzieci ulicy. Mianowicie dzieci bezdomne, te mieszkające w domu oraz w niektórych przypadkach nawet uczęszczające do szkoły, jednakże wysłane przez członków rodziny lub same decydujące się na pracę na ulicy. To właśnie one stanowią potencjalne ofiary wykorzystywania seksualnego lub nawet żyją ze świadczenia tego typu usług. Większość z nich stanowią chłopcy, dziewczynki natomiast najczęściej trafiają do domów publicznych. Dzieci trudnią się sprzedażą pamiątek, książek czy gazet i po zapoznaniu się z obcokrajowcem często zgadzają się na spotkania z dorosłymi. Mniejsze dzieci natomiast, jako bardziej podatne na perswazje, stają się ofiarami ulicznych gangów i alfonsów, niewiele starszych od nich samych, i służebniczo wykonują polecone im zadania. W samym Phnom Penh żyje wiele takich osób funkcjonujących przy sklepach, restauracjach, przy nabrzeżu. Wszędzie tam, gdzie zagranicznych turystów jest najwięcej. Mieszkają one w slumsach, noclegowniach czy na chodniku w fatalnych warunkach sanitarnych (Grillot, 2005).

Kwestia „ojców chrzestnych” natomiast sprowadza się do przejmowania nad wykorzystywanym dzieckiem szeroko rozumianej opieki. Zagraniczni przestępcy seksualni aktywnie uczestniczą w życiu dziecka przez ojcowską dyscyplinę, naukę oraz wsparcie finansowe. Zapewniają im dach nad głowa jedzenie oraz w wielu przypadkach edukację w formie lekcji języka angielskiego. Często zdarza się, iż pedofile zaopatrują w do- 
bra nie tylko samą ofiarę, ale również jej krewnych oraz osoby bliskie rodzinie. Przestępca zapewnia mieszkanie i dobra luksusowe takie jak telewizor, gry komputerowe, radio oraz najpotrzebniejsze rzeczy, na które przeciętny Khmer nie może sobie pozwolić. Zdobyte zaufanie, względnie dobre traktowanie oraz zagwarantowanie zaspokojenia podstawowych potrzeb, gwarantuje oprawcy milczenie i akceptowanie molestowania przez samą ofiarę, jak również przez jej rodzinę (Travelling, 2006).

Cicha akceptacja rodzin ofiar stwarza podłoże do innej kwestii ściśle powiązanej ze zjawiskiem wykorzystywania seksualnego, mianowicie handlu ludźmi. Sytuacja, w której osoby odpowiedzialne za jednostkę nieletnią, sprawujące nad nią opiekę nie sprzeciwiają się, a nawet wyrażają zgodę na krzywdzenie dziecka, korzystając z tego finansowo, jest idealnym przykładem szeroko zakrojonego handlu żywym towarem. To wyrażenie często kojarzy się jedynie z przemytem osób za granicę kraju, jednakże nie zawsze musi przyjmować taką formę, choć w Kambodży ten aspekt również stanowi ważną kwestię społeczną na granicy Tajlandii i Kambodży.

Proceder małżeństw mieszanych obecnie jest w procesie ograniczania. Rząd Kambodży wprowadził obostrzenia dla obcokrajowców chcących poślubić obywatelki Kambodży. Ograniczenia dotyczą maksymalnego wieku mężczyzny oraz maksymalnego dochodu miesięcznego. I tak do ślubu może dojść pomiędzy obywatelką Kambodży a nie starszym niż 50 lat mężczyzną o zarobkach nieprzekraczających 2500 dolarów amerykańskich. Rząd Królestwa Kambodży tłumaczy swoją decyzję poprawą życia kobiet w państwie, które często padają ofiarą fałszywych intencji, i co za tym idzie, wykorzystywania seksualnego i handlu ludźmi (Kamiński, 2011). Takie małżeństwa mogą generować problem pedofilii w sytuacji, gdy kobieta mająca wyjść za mąż nie przekroczyła okresu dojrzałości, a jeśli nawet go przekroczyła, jest na tyle młoda i podatna na perswazję i obietnice, że może stanowić potencjalną ofiarę wykorzystywania seksualnego. Do czynienia z pedofilią mamy również, gdy obcokrajowiec żeni się $\mathrm{z}$ obywatelką kraju, posiadającą małe dzieci. W tym przypadku ryzyko popełnienia przestępstwa wzrasta.

Wykorzystywanie seksualne dzieci przez zagranicznych turystów, celowo przybywających do Kambodży dla zrealizowania swoich fantazji erotycznych, tworzy szereg konsekwencji fizycznych i psychicznych u ofiar. Również należy pamiętać o społeczno-kulturowych efektach tego procederu, jakimi są rozwój innych patologii społecznych i obniżenie stanu zdrowia osób zaangażowanych, jak również pogłębianie się niechęci do mówienia o sprawach trudnych wywodzącej się z kultury Khmerskiej.

Osoba doświadczająca przestępstwa, zwłaszcza natury seksualnej staje się ofiarą w dwojakim wymiarze. Negatywnej modyfikacji ulega jej osobowość oraz destrukcji - fizyczność. Każdy czyn ma mniejszy lub większy wpływ na zmiany osobowościowe oraz prowadzi do niedostosowania społecznego jednostki, która w przypadku pedofilii dopiero wkracza w wiek obcowania z innymi. Częste jest również powielanie wzorców stosowanych zachowań przez ofiarę, co dalej prowadzi do wzrostu liczby osób borykających się z dewiacjami seksualnymi (Podgajna-Kuśmierek, 2003: 81-82).

Do fizycznych konsekwencji eksploatowania dzieci, często przed osiagnięciem wieku dojrzałości, zaliczyć można aspekt zdrowotny, stanowiący rosnący problem w Kambodży. Społeczeństwo khmerskie doświadcza wzrostu zachorowalności na Zespół Nabytego Niedoboru Odporności. Obecnie zarażonych wirusem HIV oraz cho- 
rych na AIDS w Królestwie jest 63 tysiące na populację liczącą 14952665 mieszkańców. W 2009 r. z powodu choroby umarło 3100 osób (The World Factbook Cambodia, 2012). Zagrożenie zarażenia się wirusem HIV przez osoby korzystające z usług seksualnych nieletnich sprawia, iż sięgają oni po coraz młodsze „nieskażone” dzieci.

Aspekt kulturowy przestępstwa ma związek z nieporuszaniem tematów trudnych, tzw. tabu w kulturze khmerskiej. Zwyczaje w Kambodży charakteryzują się nieokazywaniem uczuć, które mogą świadczyć o słabości. Takie postrzeganie rzeczywistości jest efektem długotrwałej i intensywnej polityki Czerwonych Khmerów. W tej sytuacji większość ofiar nie informuje o przestępstwie, myśląc iż są po prostu słabe i powinny sobie poradzić z problemem w pojedynkę. Również kwestia wieku i hierarchii społecznej jest impulsem do tego typu zachowań.

Konsekwencją nielegalnych praktyk seksualnych jest pogłębienie się różnic płciowych i dyskryminacji. Niższa pozycja kobiet w Kambodży oraz innych państwach Azji Południowo-Wschodniej skutkuje piętnowaniem ofiar wykorzystywania seksualnego płci żeńskiej, nie gwarantując im możliwości dochodzenia praw, za to ignorując poczynania przestępców (Władze, 2010).

Oprócz wyżej wspomnianych efektów pedofilii i seksturystyki istnieje wiele innych, do których dostęp jest ograniczony. W interesie rządu Kambodży nie jest ujawnianie gorszących i druzgocących danych, które mogą negatywnie wpłynąc na sytuację gospodarczą w aspekcie turystyki. Na szczęście istnieje wiele organizacji pozarządowych działających na rzecz pomocy ofiarom wykorzystywania seksualnego.

Po latach wojen i konfliktów, Królestwo Kambodży stanęło twarzą w twarz z głębokim kryzysem gospodarczym, wyniszczeniem terenu oraz szeregiem problemów społecznych, które przez długi okres czasu pogłębiały się i utrwalały. Obecnie podejmuje się próby zwalczenia lub zminimalizowania zjawisk, degradujących khmerskie społeczeństwo. W celu poprawy jakości życia i bezpieczeństwa ludności działalność rozpoczęło wiele organizacji pozarządowych funkcjonujących regionalnie na terenie państwa oraz organizacji międzynarodowych, które prowadzą swoje programy lub nastawione są na pomoc krajom Azji Wschodniej i Południowej.

Na uwagę zasługuje lokalna organizacja pozarządowa, działająca non-profit i niemająca charakteru politycznego. Jej istnienie warunkuje misja pomocy dzieciom, zwłaszcza tym maltretowanym, wykorzystywanym i molestowanym seksualnie. Głównym celem organizacji jest zapewnienie bezpieczeństwa dzieciom, pomoc w dochodzeniu swoich praw oraz zapewnienie im lepszego życia. Organizacja pozarządowa Coalition to Address (Sexual) Exploitation of Children in Cambodia została założona w $2001 \mathrm{r}$. przez trzy organizacje, które obrały sobie cel walki z seksualnym wykorzystywaniem dzieci. Obecnie do koalicji należą 24 organizacje. Program działania polega na ścisłej i wzajemnej współpracy w celu uniknięcia luk w procesie pomocowym i tym samym zapewnienia lepszej opieki ofiarom, wraz z równoczesnym przeciwdziałaniem przestępstwom (About Us, 2012). Kambodża, chcąc zwalczać patologie społeczne w państwie, korzysta również z pomocy społeczności międzynarodowej m.in. w formie działalności organizacji zagranicznych, prowadzących swoje programy pomocowe w Królestwie. Takimi instytucjami są np. Fundacja Somaly Mam (ang. Somaly Mam Foundation) oraz Action Pour Les Enfants (APLE). 
Pierwsza z nich jest charytatywną fundacją non-profit zaangażowaną w walkę ze współczesnym niewolnictwem na całym świecie. Jej głównym celem jest wykorzenienie handlu ludźmi, wyzwolenie jego ofiar oraz wsparcie tych, którzy przetrwali, aby mogli tworzyć swoje życie na nowo z dumą i wiarą w samych siebie. Fundacja jest szczególnie skupiona na państwach Azji Południowo-Wschodniej, ponieważ to właśnie tam handel ludźmi jest najszybciej rozwijającym się przemysłem, gdzie ponad dwa miliony kobiet i dzieci jest sprzedawanych dla potrzeb seksbiznesu. Wizją fundacji jest stworzenie świata wolnego od handlu ludźmi, a priorytetową misją pozwolenie dzieciom i kobietom na decydowanie o własnym życiu. Fundacja została założona przez Somaly Mam, która sama była ofiarą seksbiznesu w swoim rodzinnym kraju, jakim jest Kambodża. Po heroicznej ucieczce, założyła fundację pomocy i dotychczas uwolniła z niewoli aż 30 tysięcy dzieci. Fundacja Somaly Mam współpracuje z wieloma innymi organizacjami działającymi na rzecz pomocy kobietom i dzieciom, narażonych lub będących ofiarami handlu ludźmi (About Us, 2012, www.somaly.org).

Organizacja APLE jest organizacją non-profit zarejestrowaną we Francji od 1994 r. Skupiona jest na utworzeniu społeczeństwa, gdzie każdy jest wolny od wykorzystywania i molestowania. Stara się osiagnąć swój cel poprzez redukcję wszelkich form wykorzystywania seksualnego, nadmiernej eksploatacji w pracy poprzez ostrzeżenia, przeciwdziałanie, ochronę oraz promocję wnoszenia oskarżeń. Organizacja oprócz prowadzenia szerokich i precyzyjnych badań nad zjawiskiem przemocy seksualnej, prowadzi również działalność terenową obserwując i analizując zachowania podejrzanych, zazwyczaj zagranicznych turystów. Dysponują również grupą wyspecjalizowanych osób, które docierają do ofiar wykorzystywania seksualnego i oprócz pomocy psychicznej i zdrowotnej uzyskują od nich niezbędne informacje, które mają kluczowe znaczenie w procesie oskarżania danego przestępcy (About APLE, 2012, http://www.aplecambodia.org). Wyżej wymienione organizacje oraz wiele innych funkcjonuje na terenie Kambodży bądź prowadzi tam swoje programy w celu polepszenia życia dzieci oraz zapewnienia im bezpieczeństwa. Jednakże pomoc pozarządowa i międzynarodowa to nie wszystko. Najważniejszym jest, aby sam rząd dostrzegł problem i podjął działania prewencyjne, co w tak ubogim kraju jest trudne do zrealizowania.

Problem pedofilii i seksturystyki istnieje i będzie istniał, państwo może jedynie minimalizować ich zasięg oraz prowadzić działania prowadzące do oskarżania i karania przestępców seksualnych, co z biegiem czasu sprawi, iż Kambodża przestanie być docelowym miejscem turystyki seksualnej.

\section{Bibliografia}

About APLE, Action Pour Les Enfants, http://www.aplecambodia.org, 14.05.2012.

About Us, NGO Coalition to Address (Sexual) Exploitation of Children in Cambodia, http://www.cosecam.org, 14.05.2012.

About Us, Somali Mam Foundation, http://www.somaly.org, 14.05.2012.

Achieving Cambodia's Millennium Development Goals (2010), Ministry of Planning, Phnom Pehn. 
Detyna T. (2005), Problemy społeczne Kambodży oraz wewnętrzne i międzynarodowe próby ich przezwyciężania, w: Wokót sposobów życia, kwestii społecznych $i$ wzorów ich rozwiazywania, (red.) K. Frysztacki, M. Korzeniowski, Opole.

Gourley S. (2009), The Middle way. Bridging the Gap Between Cambodian Culture and Children's rights.

Grillot C. (2005), ,, Street Pedophilia” in Cambodia - A survey on Phnom Penh's suspects and victims, APLE report.

Children's Rights (2009), NGO Committee on the Rights of the Child report.

Jarosz E. (1998), Przemoc wobec dzieci. Reakcje środowisk szkolnych, Katowice.

Kamiński R. (2011), Ograniczenia dla matżeństw mieszanych w Kambodży, http://www.azjapacyfik.pl, 28.10.2011.

Keane K. (2006), Street-based child sexual exploitation in Phnom Penh and Sihanoukville: a profile of victims, APLE report.

Klimasiński K. (2000), Elementy psychopatologii i psychologii klinicznej, Kraków.

Konwencja Narodów Zjednoczonych przeciwko międzynarodowej przestępczości zorganizowanej (2000), Dz. U. z dnia 31 stycznia 2005 r.

Koss M. (2007), Międzynarodowe instrumenty zwalczania handlu dziećmi, w: Handel dziećmi. Wybrane problemy, (red.) Z. Lasocik, M. Koss, Ł. Wieczorek, Warszawa.

Morawska A. (2006), Handel dziećmi - zarys zjawiska, w: Handel ludźmi. Zapobieganie i ściganie, (red.) Z. Lasocik, Warszawa.

Nesbitt C. (2007), From invisible to indivisible. Promoting and protecting the right of the girl child to be free from violence, UNICEF report.

Paillard H. (2006), Study on Cambodia's Criminal Justice System with focus on Prosecuting Foreig Child Sex Offenders, APLE report.

Podgajna-Kuśmierek M. (2003), Pedofilia. Zarys zagadnienia, Kraków.

Pospiszyl I. (2008), Patologie spoteczne. Resocjalizacja, Warszawa.

Reported Cases of Sexual Abuse in Cambodia in the First Half of 2010 (2010), http://www.cseccenter.org.kh, 16.04.2012.

Renault R. (2006), Survey on street-based Child Sexual Exploitation In Cambodia, APLE report.

The World Factbook: Cambodia, http:// www.cia.gov, 14.05.2012.

Travelling sex offenders. Grooming abroad: the Cambodian context (2006), APLE report.

Władze Kambodży musza chronić ofiary przemocy na tle seksualnym (2010), Raport Amnesty International, http://www.amnesty.org.pl, 7.05.2012.

Vermeulen G. (2006), Handel kobietami i dziećmi - perspektywa międzynarodowa, w: Handel ludźmi. Zapobieganie i ściganie, (red.) Z. Lasocik, Warszawa.

\section{STRESZCZENIE}

Artykuł prezentuje pewien zakres problemów społecznych we współczesnej Kambodży, będących efektem przemian politycznych oraz uwarunkowań ekonomicznych w państwie. Omawianym procederem jest kwestia pedofilii i seksturystyki, która stanowi formę handlu dziećmi i jest zjawiskiem rozwijającym się na podłożu niekorzystnej sytuacji gospodarczej państwa. W artykule zaprezentowano teoretyczne podstawy omawianych zjawisk jak również obraz sytuacji we współczesnej Kambodży. Przedstawiono także organizacje pozarządowe podejmujące działania w celu likwidacji problemów społecznych oraz minimalizowania ich negatywnych skutków. 


\title{
SOCIAL SECURITY IN CONTEMPORARY CAMBODIA: THE ISSUE OF PEDOPHILIA AND SEX TOURISM AS ONE OF THE ASPECTS OF CHILD TRAFFICKING
}

\begin{abstract}
The article presents a range of social problems in contemporary Cambodia, resulting from the political and economic conditions in the country. The discussed practice is the issue of pedophilia and sex tourism, which is a form of children trafficking and is a phenomenon growing on the ground of economic disadvantages of state. The paper presents the theoretical basis of these phenomena as well as picture of the situation in contemporary Cambodia. There is also presented non-governmental organizations taking action to remedy social problems and to minimize their negative effects.
\end{abstract}


